\title{
In vitro antifungal activity of plant extracts (Sterilized and unsterilized) against Macrophomina phaseolina (Tassi) Goid. cause stem canker of pigeonpea [Cajanus cajan (L.) Millsp.]
}

Mulji Jehani and D.M. Pathak*

Department of Plant Pathology, College of Agriculture, Navsari Agricultural University,Campus Bharuch, Maktampur (Gujarat) India

\section{ARITCLE INFO}

Received : 10.07 .2019

Revised : 21.08 .2019

Accepted : 07.09.2019

\section{KEY WORDS :}

Stem canker, In vitro, Antifungal, Plant extracts
*Corresponding author:

Email : dmpathak@nau.in

\begin{abstract}
The present paper reports the antifungal activity of plant extracts ( $5 \%$ Concentration) from seven plant species viz., Bougainvillea spectabilis, Zingiber officinali, Datura stramonium, Curcuma longa, Ocimum sanctum, Hibiscus bombycideron, Tegetes erecta. Antifungal activity was tested against Macrophomina phaseolina. All plant extracts (sterilized and unsterilized) exhibited considerable distinction in radial mycelial growth of tested pathogen. Overall, Curcuma longa appeared significantly the most effective and suppressed the radial mycelial growth (sterilized plant extract, $47.13 \%$ and unsterilized plant extract, $48.28 \%$ ) of the Macrophomina phaseolina. However, Ocimum sanctum exhibited minimum inhibition (sterilized plant extract, $25.29 \%$ and unsterilized plant extract, $22.99 \%$ ) against Macrophomina phaseolina. It may be concluded from the present investigation that Curcuma longa can be utilized for the management of Macrophomina phaseolina.
\end{abstract}

How to view point the article : Jehani, Mulji and Pathak, D.M. (2019). In vitro antifungal activity of plant extracts (Sterilized and unsterilized) against Macrophomina phaseolina (Tassi) Goid. cause stem canker of pigeonpea [Cajanus cajan (L.) Millsp.]. Internat. J. Plant Protec., 12(2) : 105-109, DOI : 10.15740/HAS/IJPP/12.2/105-109, Copyright@ 2019: Hind Agri-Horticultural Society. 